\title{
Effects of milk production level and physiological stage on insulin resistance in lactating goats
}

\author{
A Sleiman-Haidar, P Schmidely, P Bas, D Sauvant, J Hervieu, P Morand-Fehr \\ INRA, station de Nutrition et Alimentation de IIINA-PG, 16, rue Claude-Bernard, \\ 75231 Paris Cedex 05, France
}

An impairment of insulin (INS) stimulated glucose utilization partitioning during lactation has been indicated as a contributing factor to the partitioning of glucose (GLU) between the mammary gland and the other tissues (Debras et al, 1989).

To obtain further information on the effects of physiological stage and milk production level on INS resistance and GLU homeostasis, plasma GLU, non esterified fatty acids (NEFA) and INS response of 11 multiparous goats to intravenous INS challenge (IVIC) were studied at 2 lactation stages (LS), LS1 $=12 \mathrm{wk}, \mathrm{LS} 2=17 \mathrm{wk}$, and at 2 milk production levels (ML) at each stage: ML1LS1 $=3.8 \mathrm{~kg} 3.5 \%$ fat corrected milk $(\mathrm{FCM}), \mathrm{ML2LS1}=2.7 \mathrm{~kg} \mathrm{FCM}, \mathrm{MLILS2}=3.4$ $\mathrm{kg} \mathrm{FCM}, \mathrm{ML} 2 \mathrm{LS} 2=2.4 \mathrm{~kg} \mathrm{FCM}$.

Goats were injected with $11.5 \mu \mathrm{g}$ insulin $/ \mathrm{kg}$ live weight directly after the morning milking. Blood samples were collected before injection and at 2, 6, 10, 14, 18, 22, 46, 62 and $88 \mathrm{~min}$ post-injection. Feed and water were withheld during blood sampling. Basal GLU, NEFA and INS plasma concentrations averaged $562 \mathrm{mg} /$, $127 \mu \mathrm{eq} / \mathrm{l}$ and $0.38 \mathrm{ng} / \mathrm{ml}$, respectively. Under our conditions, neither LS nor ML affected these concentrations.

IVIC resulted in a rapid decrease of GLU concentration to reach the lowest point $30 \mathrm{~min}$ post-injection. The LS effect tended towards significance $(P<0.11)$, ie $35 \%$ vs $28 \%$ of the initial concentration (IC) for LS1 and LS2 respectively. The ML-LS effect was significant $(P<0.03)$ for ML1LS1 (42.8\% IC) compared to ML1LS2, ML2LS1, ML2LS2 (25.6\% IC; $26.0 \%$ IC and $29.0 \% \mathrm{IC}$, respectively). NEFA de- creased through the first $18 \mathrm{~min}$ to $\approx 75.7 \%$ $\mathrm{IC}$ and then peaked at $46 \mathrm{~min}$ to attain $312 \%$ IC. NEFA for ML1 goats peaked at $347 \%$ IC compared to $280 \%$ IC $(P<0.08)$ for the ML2 goats. The values of the INSO parameter of the adjustment of the INS elimination curve per unit time (t) to a nonlinear monocompartmental model (INS = INSO $\cdot e^{-k t}$ ), was affected by milk yield, ie $65 \mathrm{ng} / \mathrm{ml}$ vs $77 \mathrm{ng} / \mathrm{ml}$ for ML1 and ML2, respectively, $P<0.02$. Goats in the ML2LS2 group attained a significantly higher INSO (78 $\mathrm{ng} / \mathrm{ml}$ ) than those in the ML1LS1 group (66 $\mathrm{ng} / \mathrm{ml}, P<0.07$ ) and the ML1LS2 group $(65 \mathrm{ng} / \mathrm{ml}, P<0.04)$. The $k$ value was equal to 0.069 and did not differ significantly between groups.

Goats with a higher milk production level at an earlier stage were more resistant to INS, which is in agreement with the literature, and may be due to a lower level of GLU extramammary utilization. These goats also had a larger INS compartment. It should be noted however, that closer measurement points are required to accurately analyze the INS utilization parameters. The higher NEFA delayed response may, by providing more glycerol and fatty acid moities, be another aspect of the adipose tissue energy homeostasis of highyield animals.

Debras E, Grizard J, Aina E, Tesseraud S, Champredon C, Arnal M (1989) Am J Physiol 256, E295-E302 